\title{
PUS3 mutations are associated with intellectual disability, leukoencephalopathy, and nephropathy
}

Anderson Rodrigues Brandão de Paiva, MD, David S. Lynch, MD, PhD, Uirá Souto Melo, PhD, Leandro Tavares Lucato, MD, PhD, Fernando Freua, MD, Bruno Della Ripa de Assis, MD, Isabella Barcelos, MD, Clarice Listik, MD, Diego de Castro dos Santos, MD, Lúcia Inês Macedo-Souza, PhD, Henry Houlden, MD, PhD, and Fernando Kok, MD, PhD

Neurol Genet 2019;5:e306. doi:10.1212/NXG.0000000000000306

Mutations in PUS3, which encodes a highly conserved enzyme responsible for posttranscriptional modification of tRNA, have been shown in a single family to be a cause of nonsyndromic intellectual disability (ID). ${ }^{1}$ In this study, we used whole-exome sequencing (WES) to identify biallelic mutations in PUS3 associated with syndromic ID with dysmorphic features, white matter disease (WMD), and renal abnormalities in a nonconsanguineous family from Brazil.

\section{Clinical findings}

We evaluated 2 sisters (figure, A) who had ID, renal abnormalities, diffuse WMD, and dysmorphic features. Their brother was similarly affected and died at age 22 years of complications of renal disease. The parents were nonconsanguineous from Northeast Brazil and Southern Italy. We obtained approval from the institutional ethics committee and written informed consent from family members.

The first patient (P1; III-3; figure, A) was noted to have global developmental delay after age 1 year. As a child, she could understand short sentences, but expressive language was limited to monosyllables. She was diagnosed with profound ID but was independent in basic activities of daily living (ADLs). She had 2 focal dyscognitive seizures with secondary generalization, at age 18 and 23 years, responsive to carbamazepine. At age 37 years, asymptomatic proteinuria and reduced creatinine clearance were detected. At 44 years, she developed psychosis, with prominent auditory and visual hallucinations and episodes of aggression. Physical examination revealed her to be on the 10th centile for height, weight, and head circumference and to have genu valgum. In addition, neurologic examination revealed dysarthria, pseudobulbar affect, with impaired gait and balance.

The second patient (P2; III-6; figure, A) also presented with short stature, neurodevelopmental delay, and dysmorphic features. She was diagnosed with acute nephritis at age 6 months and coeliac disease at age 5 years. She also developed generalized phenobarbital responsive seizures. She was able to walk and could complete ADLs with assistance. At age 20 years, she developed nephrotic syndrome due to focal segmental glomerulosclerosis (FSGS) with mesangial granular deposits and positive IgM and C3 immunofluorescence. She did not respond to steroids and developed end-stage renal failure requiring hemodialysis. Physical examination revealed that she was on the 3rd centile for height, weight, and head circumference and to have gray

\author{
Correspondence \\ Dr. de Paiva \\ arbrandaopaiva@gmail.com
}



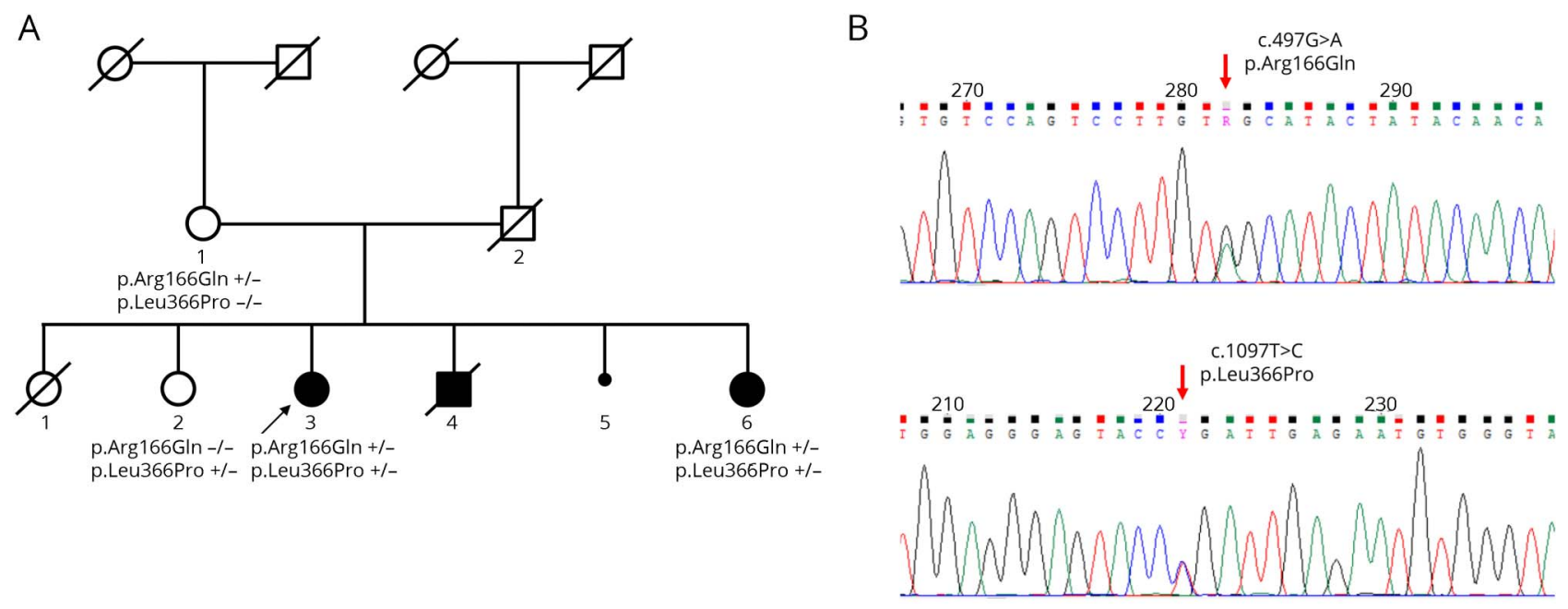

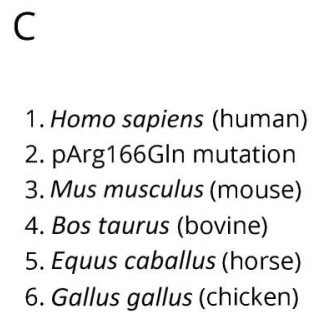

1. Homo sapiens (human)

2. pArg166GIn mutation

3. Mus musculus (mouse)

4. Bos taurus (bovine)

5. Equus caballus (horse)

6. Gallus gallus (chicken)
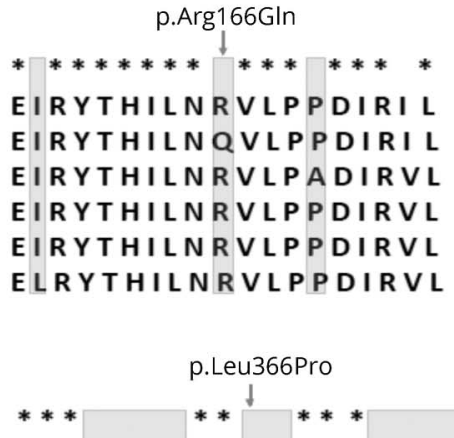

VKTHMLYSMLQG LDTVP V P VKTHMLYSMPQGLDTVP VP VKTHMLYSMLQG LDSVMVT VKTQMLYSMLQGLDSVA LP VKTH I VYSMLQGLDSAA V P VKTQVLHSMLR GLDTAPMA
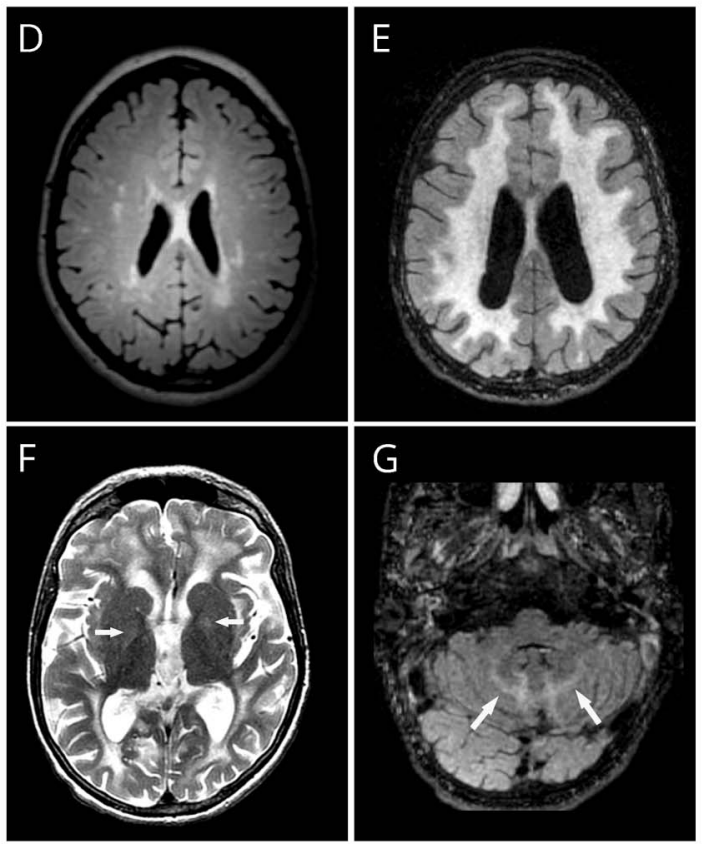

(A) Family pedigree: 2 affected individuals were compound heterozygotes for p.Arg166Gln and p.Leu366Pro PUS3 mutations, whereas their healthy mother and sister were heterozygotes for only 1 of the mutations. (B) Sanger sequencing electropherograms showing both c.497G $>A$ (p.Arg166Gln) and c.1097T>C (p.Leu366Pro) PUS3 mutations. (C) Vertebrate protein sequencing alignment showing conserved amino acid sites for both PUS3 mutations. (D) Scattered FLAIR hyperintensities in the cerebral white matter in P1. (E) Symmetric diffuse FLAIR hyperintensity in the cerebral white matter in P2. (F) Axial T2-weighted image discloses not only the white matter changes in P2 but also mild T2 hyperintensity in the globus pallidus bilaterally (arrows). One can notice also in P2 symmetric FLAIR hyperintensities in the cerebellar white matter (arrows in G), together with signs of brain parenchyma volume loss (E-G).

sclera, genu valgum, pseudobulbar affect, and dysarthria. She died at age 40 years of complications of community-acquired pneumonia.

\section{Neuroimaging findings}

MRI identified white matter abnormalities in both patients. In $\mathrm{P} 1$, there were scattered T2/fluid-attenuated inversion recovery (FLAIR) hyperintensities in the cerebral white matter, more prominent in periventricular zones (figure, D). In P2, there was symmetric diffuse T2/FLAIR hyperintensity in the cerebral and cerebellar white matter with extension to the subcortical areas, mild T2 hyperintensity in the globus pallidus bilaterally, and signs of brain parenchymal volume loss (figure, E-G). There was no gadolinium enhancement or areas of restricted diffusion.

\section{Genetic findings}

We performed WES on both patients and filtered the data for a presumed autosomal recessive inheritance pattern. There were no regions of homozygosity and no shared rare homozygous variants. However, when filtered for damaging, rare compound heterozygous mutations, we identified biallelic mutations only in PUS3 (p.Arg166Gln;p.Leu366Pro) 
(figure, B). Both are very rare and highly conserved residues among vertebrates. We confirmed the mutations by Sanger sequencing and demonstrated that they were inherited in trans.

\section{Discussion}

PUS3 codes for pseudourydilate synthase, a highly conserved enzyme responsible for posttranscriptional modification of tRNA, ${ }^{2}$ which is critical for its structure, function, and stability. Most of these modifications have been recently recognized in a growing number of human genes leading to ID-FTSJ1, TRMT1, NSUN2, WDR4, ADAT3, and PUS3. ${ }^{3}$

The original report of PUS3-related disorder describes a family with 3 affected individuals (age: $3-15$ years) from Saudi Arabia with severe ID, multifocal white matter changes, and in a single patient, epilepsy. No nephropathy was reported. WES detected a homozygous truncating mutation (p.Arg435Ter), predicting to lead to a loss of function. In our patients, affected individuals have a milder intellectual compromise and developed proteinuria/ nephrotic syndrome after age 20 years. In addition, the white matter abnormalities were more extensive in our patients.

Of interest, a well-known mechanism of WMD is disruption of protein translation as is seen in mutations in mitochondrial aspartate (DARS2) or glutamate (EARS2) transfer-RNA synthase. It is also noteworthy that leukoencephalopathies usually cause progressive neurologic deterioration and not static encephalopathy with ID, as occurred in our patients.

The late-onset renal involvement observed in our patients expands the phenotype of PUS3-related disorder. Steroidresistant FSGS has been rarely associated with mutations in mitochondrial tRNA in patients with other features typical of mitochondrial dysfunction. ${ }^{4-7}$ Recently, tubulopathy was reported in deficiency of tRNA N6-adenosine threonylcarbamoyltransferase, an enzyme involved in posttranscriptional tRNA modification.

This study expands the known phenotypic and allelic spectrum of PUS3-related disorder. In addition, it provides further evidence of the relevance of posttranscriptional modification of tRNA in neurologic diseases. Given these additional findings, we believe the phenotypic spectrum of PUS3 mutations to be wider than the initial report.

\section{Acknowledgment}

The authors thank the patients and their family for participating in this study.

\section{Study funding}

No targeted funding reported.

\section{Disclosure}

A.R.B. de Paiva, D.S. Lynch, and U.S. Melo report no disclosures. L.T. Lucato has received speaker honoraria from Bracco Imaging
Appendix 1. Author contributions

\begin{tabular}{|c|c|c|c|}
\hline Name & Location & Role & Contribution \\
\hline $\begin{array}{l}\text { Anderson } \\
\text { Rodrigues } \\
\text { Brandão de } \\
\text { Paiva, MD }\end{array}$ & $\begin{array}{l}\text { Neurogenetics Unit, } \\
\text { Neurology Department, } \\
\text { Hospital das Clínicas da } \\
\text { Universidade de São } \\
\text { Paulo, São Paulo, Brazil }\end{array}$ & Author & $\begin{array}{l}\text { Study concept } \\
\text { and design, } \\
\text { acquisition of } \\
\text { data, and writing } \\
\text { the manuscript. }\end{array}$ \\
\hline $\begin{array}{l}\text { David S. } \\
\text { Lynch, MD, } \\
\text { PhD }\end{array}$ & $\begin{array}{l}\text { UCL Institute of } \\
\text { Neurology, London, } \\
\text { United Kingdom }\end{array}$ & Author & $\begin{array}{l}\text { Study concept } \\
\text { and design, } \\
\text { acquisition of } \\
\text { data, and writing } \\
\text { the manuscript. }\end{array}$ \\
\hline $\begin{array}{l}\text { Uirá Souto } \\
\text { Melo, PhD }\end{array}$ & $\begin{array}{l}\text { Human Genome and } \\
\text { Stem Cell Research } \\
\text { Center, Department of } \\
\text { Genetics and } \\
\text { Evolutionary Biology, } \\
\text { Instituto de Biociências, } \\
\text { Universidade de São } \\
\text { Paulo, São Paulo, Brazil }\end{array}$ & Author & $\begin{array}{l}\text { Acquisition of } \\
\text { data and critical } \\
\text { revision of the } \\
\text { manuscript. }\end{array}$ \\
\hline $\begin{array}{l}\text { Leandro } \\
\text { Tavares } \\
\text { Lucato, MD, } \\
\text { PhD }\end{array}$ & $\begin{array}{l}\text { Neuroradiology } \\
\text { Section, Hospital das } \\
\text { Clínicas da } \\
\text { Universidade de São } \\
\text { Paulo, São Paulo, Brazil }\end{array}$ & Author & $\begin{array}{l}\text { Acquisition of } \\
\text { data and critical } \\
\text { revision of the } \\
\text { manuscript. }\end{array}$ \\
\hline $\begin{array}{l}\text { Fernando } \\
\text { Freua, MD }\end{array}$ & $\begin{array}{l}\text { Neurogenetics Unit, } \\
\text { Neurology Department, } \\
\text { Hospital das Clínicas da } \\
\text { Universidade de São } \\
\text { Paulo, São Paulo, Brazil }\end{array}$ & Author & $\begin{array}{l}\text { Acquisition of } \\
\text { data and critical } \\
\text { revision of the } \\
\text { manuscript. }\end{array}$ \\
\hline $\begin{array}{l}\text { Bruno Della } \\
\text { Ripa de Assis, } \\
\text { MD }\end{array}$ & $\begin{array}{l}\text { Neurogenetics Unit, } \\
\text { Neurology Department, } \\
\text { Hospital das Clínicas da } \\
\text { Universidade de São } \\
\text { Paulo, São Paulo, Brazil }\end{array}$ & Author & $\begin{array}{l}\text { Acquisition of } \\
\text { data and critical } \\
\text { revision of the } \\
\text { manuscript. }\end{array}$ \\
\hline $\begin{array}{l}\text { Isabella } \\
\text { Barcelos, MD }\end{array}$ & $\begin{array}{l}\text { Neurogenetics Unit, } \\
\text { Neurology Department, } \\
\text { Hospital das Clínicas da } \\
\text { Universidade de São } \\
\text { Paulo, São Paulo, Brazil }\end{array}$ & Author & $\begin{array}{l}\text { Acquisition of } \\
\text { data and critical } \\
\text { revision of the } \\
\text { manuscript. }\end{array}$ \\
\hline $\begin{array}{l}\text { Clarice Listik, } \\
\text { MD }\end{array}$ & $\begin{array}{l}\text { Neurogenetics Unit, } \\
\text { Neurology Department, } \\
\text { Hospital das Clínicas da } \\
\text { Universidade de São } \\
\text { Paulo, São Paulo, Brazil }\end{array}$ & Author & $\begin{array}{l}\text { Acquisition of } \\
\text { data and critical } \\
\text { revision of the } \\
\text { manuscript. }\end{array}$ \\
\hline $\begin{array}{l}\text { Diego de } \\
\text { Castro dos } \\
\text { Santos, MD }\end{array}$ & $\begin{array}{l}\text { Neurogenetics Unit, } \\
\text { Neurology Department, } \\
\text { Hospital das Clínicas da } \\
\text { Universidade de São } \\
\text { Paulo, São Paulo, Brazil }\end{array}$ & Author & $\begin{array}{l}\text { Acquisition of } \\
\text { data and critical } \\
\text { revision of the } \\
\text { manuscript. }\end{array}$ \\
\hline $\begin{array}{l}\text { Lúcia Inês } \\
\text { Macedo- } \\
\text { Souza, PhD }\end{array}$ & $\begin{array}{l}\text { Human Genome and } \\
\text { Stem Cell Research } \\
\text { Center, Department } \\
\text { of Genetics and } \\
\text { Evolutionary Biology, } \\
\text { Instituto de Biociências, } \\
\text { Universidade de São } \\
\text { Paulo, São Paulo, Brazil }\end{array}$ & Author & $\begin{array}{l}\text { Acquisition of } \\
\text { data and critical } \\
\text { revision of the } \\
\text { manuscript. }\end{array}$ \\
\hline $\begin{array}{l}\text { Henry } \\
\text { Houlden, MD, } \\
\text { PhD }\end{array}$ & $\begin{array}{l}\text { UCL Institute of } \\
\text { Neurology, London, } \\
\text { United Kingdom }\end{array}$ & Author & $\begin{array}{l}\text { Critical revision of } \\
\text { the manuscript }\end{array}$ \\
\hline $\begin{array}{l}\text { Fernando } \\
\text { Kok, MD, PhD }\end{array}$ & $\begin{array}{l}\text { Neurogenetics Unit, } \\
\text { Neurology Department, } \\
\text { Hospital das Clínicas } \\
\text { da Universidade de } \\
\text { São Paulo, São Paulo, } \\
\text { Brazil }\end{array}$ & Author & $\begin{array}{l}\text { Critical revision of } \\
\text { the manuscript }\end{array}$ \\
\hline
\end{tabular}


do Brasil and has served on the editorial board of Arquivos de Neuro-Psiquiatria. F. Freua, B.D.R de Assis, I. Barcelos, C. Listik, D. Castro Santos, and L.I. Macedo-Souza report no disclosures. H. Houlden has received governmental and/or foundation/ society support from the Medical Research Council (MRC) UK, the BRT, the MDA USA, Muscular Dystrophy UK, Ataxia UK, Muscular Dystrophy UK, Rosetrees Trust, the Wellcome Trust, and the National Institute for Health Research (NIHR) UCL/UCLH BRC. F. Kok has served on the editorial board of Arquivos de Neuro-Psiquiatria; holds a patent for methylmalonic acid determination by tandem mass spectrometry using stable isotope; is employed as Medical Director for Mendelics Genomic Analysis; has acted as a speaker for Actelion Pharmaceuticals at the NPC symposia and for BioMarin Pharmaceuticals at the CLN2 symposia; and has been a shareholder of Mendelics Genomic Analysis. Full disclosure form information provided by the authors is available with the full text of this article at Neurology.org/NG.

\section{Publication history}

Received by Neurology: Genetics August 13, 2018. Accepted in final form November 8, 2018.

\section{References}

1. Shaheen R, Han L, Faqeih E, et al. A homozygous truncating mutation in PUS3 expands the role of tRNA modification in normal cognition. Hum Genet 2016;135:707-713.

2. Hur S, Stroud RM. How U38, 39, and 40 of many tRNAs become the targets for pseudouridylation by TruA. Mol Cell 2007;26:189-203.

3. Torres AG, Batlle E, Ribas de Pouplana L. Role of tRNA modifications in human diseases. Trends Mol Med 2014;20:306-314.

4. Dinour D, Mini S, Polak-Charcon S, Lotan D, Holtzman EJ. Progressive nephropathy associated with mitochondrial tRNA gene mutation. Clin Nephron 2004;62:149-154.

5. Scaglia F1, Vogel H, Hawkins EP, Vladutiu GD, Liu LL, Wong LJ. Novel homoplasmic mutation in the mitochondrial tRNATyr gene associated with atypical mitochondrial cytopathy presenting with focal segmental glomerulosclerosis. Am J Med Genet A 2003;123A: 172-178.

6. Guéry B, Choukroun G, Noël LH, et al. The spectrum of systemic involvement in adults presenting with renal lesion and mitochondrial tRNA(Leu) gene mutation. J Am Soc Nephrol 2003;14:2099-2108.

7. Hotta O, Inoue CN, Miyabayashi S, Furuta T, Takeuchi A, Taguma Y. Clinical and pathologic features of focal segmental glomerulosclerosis with mitochondrial tRNALeu(UUR) gene mutation. Kidney Int 2001;59:1236-1243. 


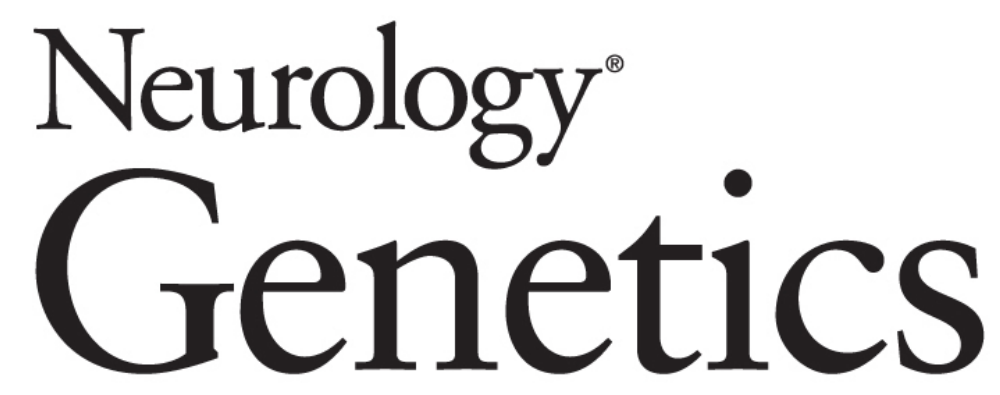

\section{PUS3 mutations are associated with intellectual disability, leukoencephalopathy, and nephropathy}

Anderson Rodrigues Brandão de Paiva, David S. Lynch, Uirá Souto Melo, et al. Neurol Genet 2019;5;

DOI 10.1212/NXG.0000000000000306

This information is current as of January 16, 2019

Updated Information \& Services

References

Subspecialty Collections

Permissions \& Licensing

Reprints including high resolution figures, can be found at: http://ng.neurology.org/content/5/1/e306.full.html

This article cites 7 articles, 1 of which you can access for free at: http://ng.neurology.org/content/5/1/e306.full.html\#\#ref-list-1

This article, along with others on similar topics, appears in the following collection(s):

All Genetics

http://ng.neurology.org//cgi/collection/all_genetics

Leukodystrophies

http://ng.neurology.org//cgi/collection/leukodystrophies

Mental retardation

http://ng.neurology.org//cgi/collection/mental_retardation

Information about reproducing this article in parts (figures,tables) or in its entirety can be found online at:

http://ng.neurology.org/misc/about.xhtml\#permissions

Information about ordering reprints can be found online:

http://ng.neurology.org/misc/addir.xhtml\#reprintsus

Neurol Genet is an official journal of the American Academy of Neurology. Published since April 2015, it is an open-access, online-only, continuous publication journal. Copyright Copyright $\odot 2019$ The Author(s). Published by Wolters Kluwer Health, Inc. on behalf of the American Academy of Neurology.. All rights reserved. Online ISSN: 2376-7839.

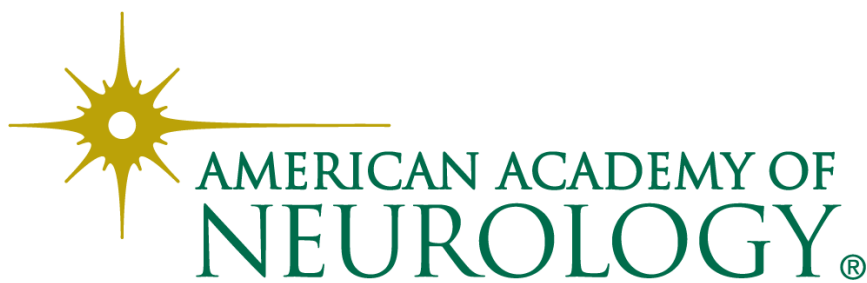

